\title{
Persistence: the key to legume performance in summer-dry hill country
}

\author{
M.B. DODD, G.W. SHEATH \\ AgResearch Ltd., Ruakura Research Centre, Private Bag 3123, Hamilton \\ mike.dodd@agresearch.co.nz
}

\begin{abstract}
In North Island hill country, a number of environmental and management factors interact to limit the performance of herbaceous legumes in pasture swards. Summer-autumn moisture stress appears to be the dominant influence, particularly because of its irregularity. Legume performance is a function of establishment success, persistence and productivity. Long-term persistence of genotypes in particular should be a primary focus in the development of new germplasm. Secondary to this is the importance of improving herbage productivity and quality. We present evidence for this view from field studies of white and subterranean clover, as well as preliminary examinations of other legume species. Key characteristics contributing to enhanced persistence are prostrate growth forms with high numbers of growing points below the grazing horizon; nodal rooting and root tolerance of low soil $\mathrm{pH}$; flowering patterns that are timed to avoid the dry period, yet sufficiently flexible to cope with the unpredictability of that period; and seed mechanisms that protect against "false strike" following shortlived summer rains.
\end{abstract}

Key words: clover, hill country, legumes, persistence, summer-dry

\section{Context - the hill country environment for legumes}

North Island summer-dry hill country pastoral environments (comprising over 4 million ha) present a challenging context for the use of temperate pasture legumes in grazed systems. Numerous factors interact to limit legume performance, such as seasonal moisture deficits, low soil fertility, soil acidity and variable grazing pressure. Complicating these factors is the high degree of spatial variability characteristic of hill country. This is driven by the range of slope and aspect combinations (as they influence temperature and moisture regimes), slope instability and the physical and chemical disturbances of grazing animals.
Variability in the timing and intensity of rainfall events in the late summer-early autumn period, combined with low rainfall effectiveness in wetting steepland soils, can create an acute short-term drought situation (Bircham \& Gillingham 1986). This affects growth and reproduction at a crucial stage in the phenology of pasture legumes. In addition, the between-year variability in weather patterns demonstrates that these hill country sites do not have a consistent climate. For example, summer/autumn moisture balances in the western Waikato region have ranged between $+146 \mathrm{~mm}$ to $-336 \mathrm{~mm}$ through the 1990 s (Dodd et al. 2001).

While nitrogen is often the most limiting nutrient for pasture growth in hill country (Chapman \& Macfarlane 1985), phosphorus is the major nutrient constraint for legumes (Edmeades et al. 1984). White clover has been shown to be at a competitive disadvantage to browntop in accessing soil P and moisture (Jackman \& Mouat 1974), a factor contributing to clover suppression in mixed swards (Harris 1974). Trace elements such as molybdenum can also be limiting for clover production (Jaiyou et al. 1993).

The characteristically low $\mathrm{pH}(4.5-5.5)$ of many hill soils limits pasture production (Edmeades et al. 1984). Legumes are particularly sensitive to acid soils, mainly related to the sensitivity of the legume-rhizobia symbiosis. Another factor is the increase in the availability of metal cations (such as aluminium and manganese) with low pH (Edmeades et al. 1983). Red, white and subterranean clovers are moderately sensitive to $\mathrm{Al}$ in the soil solution relative to other temperate pasture species (Wheeler et al. 1992).

Throughout the course of a year, grazing pressure is highly variable in hill country. Grazing affects the competitive balance of different species in the sward indirectly through modification of the shading environment of the sward (Hay \& Hunt 1989). Grazing also has direct effects - under certain conditions of sward structure legumes are preferentially grazed; and the removal of reproductive structures is particularly detrimental to annuals (Sheath \& 
Hodgson 1989).

Overarching all of these environmental considerations is the fact that, by definition, the variable topography in hill country restricts a pasture manager's options for establishment of legumes. Oversowing is the only practical method, but the cost-effectiveness of this is marginal, given the lack of reliability in the ability of grazing systems to capture the benefits of renovated pastures (Webby et al. 1990). Frequent resowing is therefore not tenable, and oversowing clover seed with annual topdressing applications has limitations. Segregation of seed and fertiliser both in the hopper and after release, as a consequence of differing particle size, leads to uneven ground distribution (Macfarlane et al. 1987).

\section{Ecological fit determines the appropriate genotypic base}

In view of these challenges, the most appropriate approach to the development of a productive legume component is one that is initially driven by considerations of ecological fit. The primary goal is to find genotypes with key characteristics that enable them to persist in grazed pasture environments, followed by a secondary focus on improving the productive capacity of those genotypes (without compromising the primary characteristics). This philosophical approach to pasture improvement research stands in contrast to the more traditional agronomic approach - that of comparing genotypes for short-term incremental productivity gains. Such gains have been demonstrated as a result of New Zealand breeding efforts (Woodfield 1999), but the additional benefits will be lost if new cultivars lack persistence. A primary focus on persistence characteristics would require attention to three broad areas: establishment success from oversowing, vegetative growth and propagation, and reproductive propagation.

\section{Establishment success}

The association of any legume species with the appropriate rhizobial strain is an important consideration for the successful establishment of vigorous plants with nitrogen-fixing capacity. For white and subterranean clover, naturalised populations are so widespread now that effective rhizobial strains are ubiquitous in most hill country soils. However, more recent interest in alternative species highlights the need to consider this issue, since in most cases effective rhizobia will not be present in soils and inoculation via seed coating will be necessary (e.g. Caucasian clover, Patrick et al. 1994). The issue is further complicated where existing Rhizobium leguminosarium Biovar trifolii strains in soil are capable of initiating nodule development, but not establishing active nitrogen fixation in new species, e.g. arrowleaf clover (Sheath et al. 1984).

The occurrence of naturalised clover populations can also affect the establishment success of desirable cultivars through germination of resident seed banks. Field assessments of buried seed in northern North Island hill country ranged from 1 000-15 000 seeds/ $\mathrm{m}^{2}$ for subterranean clover (Macfarlane \& Sheath 1984) and averaged $\sim 1700$ seeds $/ \mathrm{m}^{2}$ for white clover (Wedderburn et al. 1996). Given typical sowing rates of 70 and 500 seeds $/ \mathrm{m}^{2}$ (i.e. 5 and $3 \mathrm{~kg} / \mathrm{ha}$ ) for these species, respectively, the potential exists for emergent resident seedlings to take advantage of the space created by resident sward suppression and outcompete introduced genotypes. This has been demonstrated in those few studies where the contribution of oversown cultivars to white clover populations has been assessed (Hopkins et al. 2000; Dodd et al. 2001).

\section{Vegetative growth}

Under conditions of close and/or continuous grazing, a prostrate habit that maintains growing points close to the ground is vital in maintaining vegetative growth. Elevation of terminal growing points into the grazing horizon leaves species such as Lotus pedunculatus and red clover vulnerable to intensive defoliation through removal of regrowth sites (Sheath \& Hodgson 1989). Recently identified red clover genotypes with a prostrate growth form have shown good persistence in hill pastures (Orr \& Wedderburn 1996). Growing point density (achieved by high levels of stolon branching) has been identified as an important factor in the persistence of hill country selections of white clover (Williams et al. 1982). Nodal rooting is another advantageous trait, because it is usually associated with prostrate stolon development and enables development of new plants after fragmentation of nodes by hoof damage. Lines of red clover and Kenya clover (T. semipilosum) with a prostrate habit and nodal rooting have shown some potential on grazed hill sites (Orr \& Wedderburn 1996).

Another morphological trait that effectively maintains growing point density close to the soil surface is the rhizomatous form, characteristic of Caucasian clover. While this species is emerging as well suited to a 
range of summer-dry environments (Black et al. 2000), it remains largely untested in North Island hill country. Defining issues for Caucasian clover in this context will likely be establishment rates and root tolerance of acid subsoils.

In terms of tolerance to the various environmental factors outlined in the first section, a number of relevant genotype screening exercises have been undertaken (e.g. phosphorus nutrition of white clover, Caradus et al. 1991; and various legume species, Dodd \& Orr 1995a,b; Al tolerance of various legume species, Wheeler \& Dodd 1995). What seems clear from such studies is that there are relatively few species (and genotypes within species) that combine tolerance to all of these factors, and there is no single superior trait on which to base selection programmes. This is not necessarily problematic, since the spatial variation in micro-environmental conditions creates a mosaic of limiting factors across the landscape. Thus there is a wide range of niches to accommodate the various species and/or genotypes with their associated strengths and weaknesses. This highlights the importance of developing and using blends (i.e. diverse seed mixes) in hill pasture mixes, and suggests the need for new research on the impact of genetic diversity per se (as opposed to the impact of specific genotypes) on legume performance.

\section{Reproductive propagation}

The importance of legume persistence through reproduction is clear for annual legumes such as subterranean clover and annual lotus species, but is the subject of some contention for perennials like white clover. Some studies have shown negligible levels of natural reseeding; therefore, the importance of flowering and seed characteristics for white clover have been dismissed (Woodfield \& Caradus 1987). However, there is evidence to show that in many cases, natural reseeding is necessary to re-establish populations of white clover after (usually) droughtinduced collapses (Macfarlane et al. 1990a). Furthermore, ecotypes collected from areas prone to such events showed distinctive shifts in reproductive phenology consistent with the development of a dual vegetative and reproductive persistence strategy (Macfarlane \& Sheath 1984). This shift involved an earlier, longer and more profuse flowering pattern, allowing seed set to occur before the onset of unpredictable summer moisture stress.

Annuals such as subterranean clover avoid the dry period by existing as seed and re-establishing populations in the autumn when adequate soil moisture levels are restored, and thus, their reproductive phenology is absolutely critical. In the case of white clover, studies have found distinctive characteristics within field populations that have undergone natural selection from original cultivar sowings. A prostrate growth form that maintains developing seed heads low in the sward is an important feature (Sheath \& Macfarlane 1990). This can be contrasted with an erect terminal seeding form, observed in arrowleaf clover, which is unable to avoid seed-head loss by grazing (Sheath et al. 1984). There is an important interaction with grazing management here. Set stocking prior to and during the flowering period enables the development of a stable grazing height, to which the subterranean clover plants adapt (Sheath \& Hodgson 1989). In contrast, rotational grazing encourages elevation of the flowers into the subsequent grazing zone. The other major characteristic of persistent subterranean clover populations is a flowering period that is late relative to most genotypes, being intermediate between 'Mount Barker' and 'Tallarook' (Macfarlane \& Sheath 1984). In persistence studies at two hill country sites, many of the available Australian-bred cultivars and lines did not exhibit these key characteristics and showed poor persistence (Sheath \& Richardson 1983; Dodd et al. 1995a,b). Thus, there was an apparent conflict between breeding for productivity (linked to an early-flowering type with an erect habit) and breeding for persistence (the late-flowering, prostrate type). It would be of interest to determine whether this dichotomy could be overcome, perhaps by selecting for early-flowering under a close grazing regime.

The ability of subterranean clover to successfully reestablish in the autumn can be linked to two seed characteristics that control germinationhardseededness and embryo dormancy (Smetham 2003). These characteristics protect the seed against "false strike", whereby isolated rainfall events promote germination only to leave the new seedling exposed to subsequent dry spells (Sheath \& Hay 1989). Again, populations of adapted resident ecotypes show high levels of hardseededness and some degree of embryo dormancy. The frequency distributions of these characteristics in the 85 northern North Island hill country populations of the Macfarlane \& Sheath (1984) study are shown in Table 1. Given the temporally variable nature of summer rainfall events in much of the hill county of the North 
Island, these seed physiological characteristics are also critical in ensuring long-term persistence of subterranean clover in pastures.

Overall, the lack of ecological fit for a large number of available legume cultivars to grazed pasture environments in hill country is evidenced by the consistent observations of population drift back to resident ecotypes over time (Wedderburn et al. 1996, Hopkins et al. 2000, Dodd et al. 2001).

Table 1 Frequency distribution of hardseededness and embryo dormancy levels in hill country populations of subterranean clover.

\begin{tabular}{lccc}
\hline $\begin{array}{l}\text { Level of } \\
\text { hard seed } \\
(\%)\end{array}$ & $\begin{array}{c}\text { \% of hill } \\
\text { country } \\
\text { populations }\end{array}$ & $\begin{array}{c}\text { Level of embryo } \\
\text { dormancy }\end{array}$ & $\begin{array}{c}\% \text { of hill country } \\
\text { populations }\end{array}$ \\
\hline$<50$ & 15 & $<20$ & 88 \\
$50-80$ & 62 & $20-50$ & 7 \\
$>80$ & 23 & $>50$ & 5 \\
\hline
\end{tabular}

\section{Productive performance depends on the genotypic base}

Having established a persistent, well-adapted legume genotype base, the ability of that population to make a contribution to forage production and nitrogen fixation (the two tend to be closely linked, Ledgard et al. 1987) becomes important. The two principal values of a robust legume component in the sward - forage quality through high protein content and an entry point for nitrogen into the system-are dependent on the ability of the grazing animal to access the foliage. Thus, there is an apparent conflict between the prostrate growth habit required for persistence and the accessibility of foliage for the grazing animal.

Attempts to increase the clover yield of hill country pastures through the introduction of new genotypes have been largely unsuccessful (Barker et al. 1988; Macfarlane et al. 1990b; Webby et al. 1990; Wedderburn et al. 1996; Dodd et al. 2001) with few exceptions (see Chapman et al. 1993). Either the new high-productivity genotypes have failed to persist, or the new persistent genotypes have shown no productivity gains over the resident ecotypes. Orr \& Wedderburn (1996) also noted no increase in overall legume content with the successful introduction of new species. A refinement of the question of yield improvements is whether it is possible to extend the period of legume production at either end of the seasonal growth curve, i.e. late winter and early summer, when climatic conditions permit. In the former case, this appears inextricably linked to flowering time and thus has negative implications for persistence as outlined previously. In terms of improving perennial legume growth into the summer, taproot characteristics take on increased importance in allowing the plant to access soil moisture reserves deeper in the profile (Woodfield \& Caradus 1987). However, acid subsoils typically inhibit the growth of deep roots in many legume species, with the notable exception of Lotus pedunculatus (Sheath \& Hay 1989).

\section{Realisation of beneficial traits depends on ecological fit}

There is currently a great deal of interest in the genetic manipulation of legumes for the inclusion of beneficial biochemical traits, such as increasing tannin content to reduce ruminant methane production. Given our observations about the contribution of new genotypes to field populations and animal diet, it seems clear that the realisation of those benefits (i.e. some improvement in animal performance that can be captured in a financial return) is dependent on their insertion into cultivars that are well adapted (and therefore persistent in grazed swards) and contribute significantly to the diet of the grazing animal.

We may gain some insight into the likely behaviour of such beneficial traits by examining the presence of existing secondary compounds in subterranean clover. The link between formononetin levels in hill county subterranean clover populations and the degree to which those populations reflect the cultivars of origin is not as strong as might be expected. There is a high level of variation in the formononetin content of populations dominated by Tallarook types (Figure 1). Typing of these 85 northern North Island hill country populations in the Macfarlane \& Sheath (1984) study was based on morphological characterisation. This indicates that the expression of any secondary compound, be it beneficial or detrimental to animal performance, will not only depend on the persistence of its 'host' genotype, but may also be diluted by population drift in the field. This could result from natural selection of genotypes within a cultivar line. 


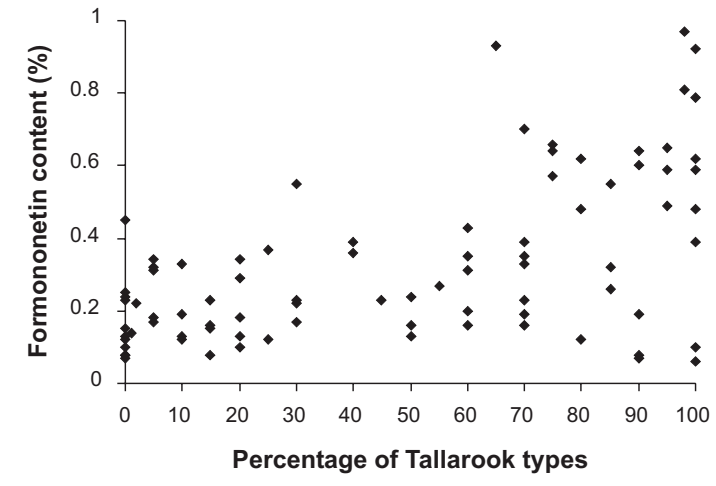

Figure 1 Variation in formononetin levels with changes in genotype frequency in hill country populations of subterranean clover.

\section{Summary - the ideal legume?}

The demanding and unpredictable environment that is North Island hill country makes the development of the ideal (i.e. persistent and productive) legume a significant challenge. Key characteristics will be a growth form with high numbers of growing points below the grazing horizon, yet the elevation of vegetative tissue into the grazing zone for animal consumption; improved vegetative growth earlier in the cool late-winter period, yet later into the dry summer period; flowering and reseeding patterns that are timed to avoid the dry period, yet flexible enough to cope with the unpredictability of that period; and seed mechanisms that protect against "false strike". It may be that further germplasm collections from homologous climatic zones (as opposed to material collected for zones homologous to Australian conditions, as in the case of subterranean clover) will include more promising genetic material. However, if such a type does not exist within the domain of herbaceous legumes, the alternatives include the use of a diverse range of species and genotypes in pasture seed mixes; hybridisation to combine desirable characteristics (e.g. white and Caucasian clover, Abberton et al. 1998); the development and use of shrub forms (Thorrold et al. 1994); or the shift to reliance on fertiliser to overcome nitrogen limitations in hill country (Gillingham et al. 2003).

\section{ACKNOWLEDGEMENTS}

We would like to thank Liz Wedderburn, Bill Lowther and the two journal referees for constructive comments on the manuscript.

\section{REFERENCES}

Abberton, M.T.; Michaelson-Yeates, T.P.T.; Marshall, A.H.; Holdbrook-Smith, K.; Rhodes, I. 1998. Morphological characteristics of hybrids between white clover, Trifolium repens L., and Caucasian clover, Trifolium ambiguum M. Bieb. Plant Breeding 117(5): 494-496.

Barker, D.J.; Chapman, D.F.; Anderson, C.B.; Dymock, N. 1988. Oversowing 'Grasslands Wana' cocksfoot, 'Grasslands Maru' phalaris and 'Grasslands Tahora' white clover in hill country at varying rates of paraquat and glyphosate. New Zealand Journal of Agricultural Research 31: 373-382.

Bircham, J.S.; Gillingham, A.G. 1986. A soil water balance model for sloping land. New Zealand Journal of Agricultural Research 29: 315-323.

Black, A.D.; Pollock, K.M.; Lucas, R.J.; Amyes, J.M.; Pownall, D.B.; Sedcole, J.R. 2000. Caucasian clover/ryegrass produced more legume than white clover/ryegrass pastures in a grazed comparison. Proceedings of the New Zealand Grassland Association 62: 69-74.

Caradus, J.R.; MacKay, A.D.; Wewala, S.; Dunlop, J.; Hart, A.L.; Lambert, M.G.; Van den Bosch, J.; Hay, M.J.M. 1991. Heritable differences in white clover for response to phosphorus: new prospects for low input pastoral systems. Proceedings of the New Zealand Grassland Association 53: 59-66.

Chapman, D.F.; Macfarlane, M.J. 1985. Pasture growth limitations in hill country and choice of species. pp. 25-30. In: Using Herbage Cultivars. Grassland Research and Practice series No. 3. Eds. Burgess, R.E.; Brock, J.L. New Zealand Grassland Association, Palmerston North.

Chapman, D.F.; Mackay, A.D.; Devantier, B.P.; Dymock, N.; Anderson, C.B. 1993. Effects of cultivar introduction and fertiliser on characteristics of white clover (Trifolium repens L.) plants and populations in a hill country pasture. New Zealand Journal of Agricultural Research 36: 87-98.

Dodd, M.B.; Orr, S.J. 1995a. Seasonal growth, phosphate response, and drought tolerance of 11 perennial legume species grown in a hillcountry soil. New Zealand Journal of Agricultural Research 38: 7-20.

Dodd, M.B.; Orr, S.J. 1995b. Seasonal growth, flowering patterns, and phosphate response of 18 annual legume species grown in a hill-country soil. New Zealand Journal of Agricultural Research 38: 21-32. 
Dodd, M.B.; Sheath, G.W.; Richardson, S. 1995a. Development of subterranean clover (Trifolium subterraneum L.) genotypes for New Zealand pastures 1 . Whatawhata persistence evaluation. New Zealand Journal of Agricultural Research 38: 33-47.

Dodd, M.B.; Sheath, G.W.; Richardson, S. 1995b. Development of subterranean clover (Trifolium subterraneum L.) genotypes for New Zealand pastures 2. Wairakei persistence evaluation. New Zealand Journal of Agricultural Research 38: 49-56.

Dodd, M.B.; Sheath, G.W.; Wedderburn, M.E.; Tarbotton, I.S. 2001. Long-term performance of white clover cultivars oversown into summer-dry hill country. Proceedings of the New Zealand Grassland Association 63: 85-90.

Edmeades, D.C.; Feyter, C.; O’Connor, M.B. 1984. Lime and phosphorus requirements for hill country yellow-brown earths. Proceedings of the New Zealand Grassland Association 45: 98-106.

Edmeades, D.C.; Smart, C.E.; Wheeler, D.M. 1983. Aluminium toxicity in New Zealand soils: preliminary results on the development of diagnostic criteria. New Zealand Journal of Agricultural Research 26: 493-501.

Gillingham, A.G.; Sheath, G.W.; Gray, M.H.; Webby, R.W. 2003. Management and nitrogen fertiliser options for increased pasture productivity in dryland hill systems. In: Moot, D.J. (ed.) Legumes for dryland pastures. Proceedings of a New Zealand Grassland Association symposium, Lincoln University, 18-19 November 2003. Grassland Research and Practice Series no. 11: 43-50.

Harris, W. 1974. Why browntop is bent on creeping. Proceedings of the New Zealand Grassland Association 35: 101-109.

Hay, R.J.M.; Hunt, W.F. 1989. Competition from associated species on white and red clover in grazed swards. pp 311-325 in Marten, G.C. et al. Persistence of Forage Legumes. American Society of Agronomy. Madison, WI.

Hopkins, A.; Lambert, M.G.; Barker, D.J.; Costall, D.A.; Sanders, P.M.; Scott, A.G.; Williams, W.M. 2000. Determination of management and topographic influences on the balance between resident and 'Grasslands Huia' white clover (Trifolium repens) in an upland pasture using isozyme analysis. Journal of Agricultural Science (Cambridge) 134(2): 137-145.

Jackman, R.H.; Mouat, M.C.H. 1974. Browntop and pasture nutrition. Proceedings of the New Zealand Grassland Association 35: 95-100.
Jaiyou, Z.; Valentine, I.; Hodgson, J. 1993. Response of southern North Island hill pasture to nitrogen, molybdenum and lime. Proceedings of the New Zealand Grassland Association 55: 63-66.

Ledgard, S.F.; Brier, G.J.; Littler, R.A. 1987. Legume production and nitrogen fixation in hill pasture communities. New Zealand Journal of Agricultural Research 30: 413-421.

Macfarlane, M.J.; Korte, C.J.; Gillingham, A.G. 1987. The effect of increasing winds on the distribution of oversown seed and fertiliser. Proceedings of the New Zealand Grassland Association 48: 131136.

Macfarlane, M.J.; McGowan, A.W.; Sheath, G.W.; Korte, C.J. 1990b. An on-farm evaluation of white and subterranean clovers in North Island hill country. Proceedings of the New Zealand Grassland Association 51: 157-162.

Macfarlane, M.J.; Sheath, G.W. 1984. Clover - what types for hill country? Proceedings of the New Zealand Grassland Association 45: 140-150.

Macfarlane, M.J.; Sheath, G.W.; McGowan, A.W. 1990a. Evaluation of clovers in dry hill country. 5. White clover at Whatawhata, New Zealand New Zealand Journal of Agricultural Research 33: 549-556.

Orr, S.J.; Wedderburn, M.E. 1996. Assessing the persistence of some pasture legumes in hill country. Proceedings of the New Zealand Grassland Association 58: 259-264.

Patrick, H.N.; Lowther, W.L.; Trainor, K.D. 1994. Inoculation for successful establishment of Caucasian clover. Proceedings of the New Zealand Grassland Association 56: 101-105.

Sheath, G.W.; Hay, R.J.M. 1989. Overview of legume persistence in New Zealand. pp 23-35 in Marten, G.C. et al. Persistence of Forage Legumes. American Society of Agronomy. Madison, WI.

Sheath, G.W.; Hodgson, J. 1989. Plant-animal factors influencing legume persistence. pp 361-374 in Marten, G.C. et al. Persistence of Forage Legumes. American Society of Agronomy. Madison, WI.

Sheath, G.W.; Macfarlane, M.J. 1990. Evaluation of clovers in dry hill country. 4. Components of subterranean clover regeneration at Whatawhata, New Zealand. New Zealand Journal of Agricultural Research 33: 541-547.

Sheath, G.W.; Macfarlane, M.J.; Bonish, P.M. 1984. Evaluation of arrowleaf clover (Trifolium vesiculosum) in North Island hill country: nodulation and reseeding. New Zealand Journal of Experimental Agriculture 12: 209-217.

Sheath, G.W.; Richardson, S. 1983. Morphology, 
flowering, and persistence of subterranean clover cultivars grown in North Island hill country: a preliminary note. New Zealand Journal of Experimental Agriculture 11: 205-208.

Smetham, M.L. 2003. Subterranean clover (Trifolium subterraneum L.): its history and current and future research in New Zealand. In: Moot, D.J. (ed.) Legumes for dryland pastures. Proceedings of a New Zealand Grassland Association symposium, Lincoln University, 18-19 November 2003. Grassland Research and Practice Series no. 11:61-72.

Thorrold, B.S.; Power, I.L.; McGowan, A.W.; Ledgard, S.F.; Brier, G.J. 1994. Matching forage plant communities to available resources. pp. 328-333. In: Proceedings of the New Zealand Conference on Sustainable Land Management. Eds. Allen, B; Mason, C; Hutchinson, G; Williams, M. Lincoln University, Canterbury.

Webby, R.W.; Sheath, G.W.; Boom, C.J. 1990. Performance of new pasture cultivars in a hill country finishing system. Proceedings of the New Zealand Grassland Association 51: 151-155.

Wedderburn, M.E.; Adam, K.D.; Greaves, L.A.; Carter, J.L. 1996. Effect of oversown ryegrass (Lolium perenne) and white clover (Trifolium repens) on the genetic structure of New Zealand hill pastures. New Zealand Journal of Agricultural Research 39: 41-52.

Wheeler, D.M.; Edmeades, D.C.; Christie, R.A.; Gardner, R. 1992. Effect of aluminium on the growth of 34 plant species: A summary of results obtained in low ionic strength solution culture. Plant and Soil 146: 61-66.

Wheeler, D.M.; Dodd, M.B. 1995. The effect of aluminium on yield and plant chemical concentrations of some temperate legumes. Plant and Soil 173: 133-145.

Williams, W.M.; Lambert, M.G.; Caradus, J.R. 1982. Performance of a hill country white clover selection. Proceedings of the New Zealand Grassland Association 43: 188-195.

Woodfield, D.R. 1999. Genetic improvements in New Zealand forage cultivars. Proceedings of the New Zealand Grassland Association 61: 3-7.

Woodfield, D.R.; Caradus, J.R. 1987. Adaptation of white clover to moisture stress. Proceedings of the New Zealand Grassland Association 48: 143149. 
